\title{
Impact of combining acerola by-product with a probiotic strain on a gut microbiome model
}

\section{Fernanda Bianchi, Natalia Pontin Lopes, Maria Angela Tallarico Adorno, Isabel Kimiko Sakamoto, Maria Inés Genovese, Susana Marta Isay Saad \& Katia Sivieri}

To cite this article: Fernanda Bianchi, Natalia Pontin Lopes, Maria Angela Tallarico Adorno, Isabel Kimiko Sakamoto, Maria Inés Genovese, Susana Marta Isay Saad \& Katia Sivieri (2019) Impact of combining acerola by-product with a probiotic strain on a gut microbiome model, International Journal of Food Sciences and Nutrition, 70:2, 182-194, DOI: 10.1080/09637486.2018.1498065

To link to this article: https://doi.org/10.1080/09637486.2018.1498065

曲 Published online: 30 Aug 2018.

Submit your article to this journal $₫$

ЦIll Article views: 161

View Crossmark data \lceil

Citing articles: 1 View citing articles 5 


\title{
Impact of combining acerola by-product with a probiotic strain on a gut microbiome model
}

\author{
Fernanda Bianchi ${ }^{a}$, Natalia Pontin Lopes ${ }^{a}$, Maria Angela Tallarico Adorno ${ }^{b}$, Isabel Kimiko Sakamoto ${ }^{b}$, \\ Maria Inés Genovese ${ }^{c}$, Susana Marta Isay Saad ${ }^{\mathrm{d}, \mathrm{e}}$ and Katia Sivieri ${ }^{\mathrm{a}}$

\begin{abstract}
aDepartment of Food and Nutrition, School of Pharmaceutical Sciences, State University of São Paulo (UNESP), Araraquara, Brazil;
bepartment of Hydraulics and Sanitation, School of Engineering of São Carlos, University of São Paulo (USP), São Carlos, Brazil; 'Department of Food and Experimental Nutrition, School of Pharmaceutical Science, University of São Paulo (USP), São Paulo, Brazil;

dDepartment of Biochemical and Pharmaceutical Technology, University of São Paulo (USP), São Paulo, Brazil; ${ }^{{ }^{2}}$ Food Research Center, University of São Paulo (USP), São Paulo, Brazil
\end{abstract}

\section{ABSTRACT}

In this study, we first investigated the survival of three probiotic strains, individually and combined with acerola by-product during simulated gastrointestinal conditions. Next, we investigated the effects of acerola by-product combined with Bifidobacterium longum BB-46 on a gut micro-

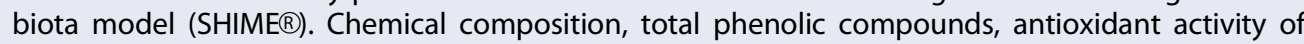
the acerola by-product and microbial counts, denaturing gradient gel electrophoresis (DGGE), ammonium ions $\left(\mathrm{NH}_{4}^{+}\right)$and short-chain fatty acids (SCFAs) analysis of the SHIME $®$ samples were performed. Acerola by-product revealed high protein and fibre, reduced lipid contents, and showed to be an excellent source of total phenolic compounds with high in vitro antioxidant activity. A decreased amount of $\mathrm{NH}_{4}^{+}$in the ascending colon and an increase $(p<.05)$ in SCFAs were observed in the three regions of colon during treatment with BB- 46 and acerola by-product. BB-46 combined with acerola by-product showed positive effects on the gut microbiota metabolism in SHIME ${ }^{\circledR}$ model.

\section{ARTICLE HISTORY}

Received 27 December 2017

Revised 4 July 2018

Accepted 4 July 2018

\section{KEYWORDS}

Probiotic; SHIME®; acerola by-product; phenolic compounds; human gut microbiota

\section{Introduction}

It is estimated that $10^{14}$ intestinal microorganisms, belonging to over 1000 different species, are distributed along the human gastrointestinal tract, with the largest population being present in the colon (Payne et al. 2012). Alterations in the intestinal microbiota composition, due to lifestyle, age, diet or immunological factors may bring several health problems, like intestinal and gastric disorders, as well as susceptibility to other diseases. The consumption of products containing probiotic microorganisms, fibres, and/or many other bioactive compounds has been an option to achieve a favourable composition of the intestinal microbiota, thereby ensuring a better quality of life (Woodmansey 2007).

Some probiotic strains are reported to confer health benefits to the consumer, such as increased resistance to diarrheal-type diseases, risk reduction of some types of cancers, lactose digestion improvement, and overall enhancement in cell-mediated immunity (Hoover 2014). The Bifidobacterium longum genome sequence determination has revealed several physiological traits which explain the successful adaptation of these bacteria to the human colon in terms of metabolic and immunomodulatory activities, and adhesion ability (Kavanaugh et al. 2013).

In addition to probiotics, there are several bioactive compounds like polyphenols and fibres, which besides having the ability to improve the probiotic viability through the gatrointestinal conditions (Sendra et al. 2016; Valero-Cases et al. 2017), can modulate the colon microbiota composition or activity, thus either increases or decreases the growth rate of certain intestinal bacteria (Duda-Chodak 2012).

A wide number of polyphenols are found in the tropical fruits, which are largely produced in Brazil (IBRAF 2009). Although, Brazil is considered the world's largest producer of tropical fruits, about $30-40 \%$ of agricultural by-products are generated during the production of juices and pulps (IBRAF 2009; Sousa et al. 2011). According to Junior et al. (2005), about $40 \%$ of acerola by-products are generated during the process of acerola juice. These

CONTACT Katia Sivieri katiasiv@hotmail.com, sivierik@fcfar.unesp.br E Department of Food and Nutrition, School of Pharmaceutical Sciences, State University of São Paulo (UNESP), Rodovia Araraquara Jaú/Km $1 \mathrm{~s} / \mathrm{n}, 14801-902$ - Araraquara- SP, Brazil

(C) 2018 Informa UK Limited, trading as Taylor \& Francis Group 
by-products may contribute to increased production of organic waste, causing serious environmental problems as well as economic losses to the industry (Sousa et al. 2011).

Studies have shown that, besides being rich in many nutrients, tropical fruits have high content of fibres and other bioactive compounds, mostly concentrated in the skin and seeds (Gorinstein et al. 2011). Acerola (Malpighia emarginata D.C.) is a tropical fruit rich in phytochemicals with proven antioxidant activities, and it is commonly known as an excellent vitamin C source (Mezadri et al. 2008). Many reports are found in the literature describing the advantageous chemical composition of acerola fruit, as well as its antioxidant activity (Oliveira et al. 2009; Rufino et al. 2010; Silva et al. 2014). Realini et al. (2015) have characterised a dried acerola by-product, and concluded that it could be reused for various purposes as a source of bioactive compounds, thereby avoiding its disposal into the environment. The acerola by-product can be used as flour or be added to different flours, improving the nutritional value of several food products, like bread and cookies (Marques et al. 2013).

Therefore, this study aimed to select a combination between the acerola by-product and a probiotic strain, among Lactobacillus acidophilus LA-5, Lactobacillus paracasei L-431 or Bifidobacterium longum BB-46, based on the highest probiotic survival results during simulated gastrointestinal conditions and to investigate the effects of the selected combination on a gut microbiota model (SHIME®). The evaluation and the evidences of positive effects of the acerola by-product in combination with the probiotic strain on the intestinal microbiota can encourage the development of new functional products, generating an added value to the acerola by-product, often discarded by the food processing industries.

\section{Materials and methods}

\section{Acerola by-product preparation and characterisation}

\section{Preparation of the acerola by-product}

Ripe acerola ( $M$. emarginata D.C.), cabocla variety, São Paulo region cultivation, was purchased from a frozen distributor (Pura Polpa, Araraquara, Brazil). The dried acerola by-product (dried skin, seeds and residues of pulp) was produced in the laboratory. For this purpose, sanitisation and bleaching of the fresh fruits was conducted, followed by crushing in a sieve $(0.5 \mathrm{~mm}$ mesh) and drying the by-product in an oven at $60{ }^{\circ} \mathrm{C}$ for $24 \mathrm{~h}$. Subsequently, the dry by-product was treated in a blender $(1 \mathrm{~min}$.) and sieved $(0.5 \mathrm{~mm}$ mesh) in order to obtain a powder. The concentration of the by-product $(2.5 \%(\mathrm{w} / \mathrm{v}))$ was based on the minimum level established by the Brazilian Health Regulatory Agency (Anvisa, 2012) for food to be considered as the source of fibre.

\section{Chemical composition determination}

The acerola by-product was analysed for lipid content (L) (Soxhlet method), protein content (P) (micro-Kjeldahl method), and for moisture content (M) and ash content (A), respectively, by the methods of drying in an oven at $105^{\circ} \mathrm{C}$, and incinerating at $550^{\circ} \mathrm{C}$. The total fibre content was obtained by the non-enzymatic gravimetric method. All methods were in accordance with the AOAC (2010). The total carbohydrate content of the acerola by-product was calculated by the difference.

\section{Phenolic compounds extraction}

Samples (1 $\mathrm{g}$ ) of the dried acerola by-product were extracted in triplicates with $20 \mathrm{~mL}$ of aqueous methanol (methanol: water, 70: $30 \mathrm{v} / \mathrm{v}$ ), for one hour at $25^{\circ} \mathrm{C}$, with a magnetic stirrer. Afterwards, it was centrifuged (at $10000 \mathrm{rpm}$ ) for $15 \mathrm{~min}$ at $10^{\circ} \mathrm{C}$. Next, the supernatant was kept and pellet re-extraction was performed by adding $20 \mathrm{~mL}$ of aqueous methanol (methanol: water, 70: $30 \mathrm{v} / \mathrm{v}$ ) and mixing it in an ultra turrax (Polytron-Kinematica GnbH- Luzers, 3 times for $1 \mathrm{~min}$ at speed 4$)$. After this process, the solution was again centrifuged $(10000 \mathrm{rpm}$ for $15 \mathrm{~min}$ at $10^{\circ} \mathrm{C}$ ), the supernatant was added to the kept one and their volume completed to $50 \mathrm{~mL}$ with aqueous methanol (methanol: water, 70: $30 \mathrm{v} / \mathrm{v}$ ) (Nóbrega et al. 2015).

\section{Total phenolic content}

The analysis was performed according to the methodology proposed by Singleton et al. (1999) with some modifications (Genovese et al. 2003). An aliquot $(0.25 \mathrm{~mL})$ of extract was mixed with $0.25 \mathrm{~mL}$ Folin-Ciocalteu reagent and $2 \mathrm{~mL}$ distilled water. After 3 minutes at room temperature, $0.25 \mathrm{~mL}$ of a saturated sodium carbonate solution $\left(\mathrm{Na}_{2} \mathrm{CO}_{3}\right)$ was added and the mixture was kept at $37^{\circ} \mathrm{C}$ in a water bath for 30 minutes. The absorbance was measured at $750 \mathrm{~nm}$ through an Ultrospec 2000 spectrophotometer model (Amersham Biosciences, Cambridge, U.K.). Gallic acid was used as reference standard. Results 
were expressed in gallic acid equivalent (GAE) in $\mathrm{mg} / \mathrm{g}$ of sample on a dry basis.

Antioxidant activity by FRAP (ferric reducing ability of plasma) and DPPH (sequestration of radical 2.2difenyl-1-picrylhydrazyl)

The antioxidant activity was determined by FRAP, according to Benzie and Strain (1996). Briefly, $20 \mathrm{uL}$ of the diluted extract and $150 \mathrm{uL}$ of the FRAP reagent (sodium acetate buffer/TPTZ solution/HCl solution) were added to a 96 wells polystyrene microplate (Costar, Cambridge, MA). After 5 minutes of incubation at $37^{\circ} \mathrm{C}$, the absorbance was read at $593 \mathrm{~nm}$ with a Benchmark Plus Microplate Spectrophotometer (Synergy $^{\mathrm{TM}} \mathrm{H} 1$, Biotek Instruments Inc., Vermont, USA). The results were expressed in $\mu$ moles of Trolox equivalents (TE) per $g$ of sample (d.b.) and carried out in triplicates.

The antioxidant activity was also determined by $\mathrm{DPPH}^{\bullet}$, according to Brand-Williams et al. (1995) with modifications proposed by Duarte-Almeida et al. (2006). After 20 minutes of reaction time, the absorbance was read at $517 \mathrm{~nm}$ on a microplate spectrophotometer and converted to antioxidant activity percentage terms. The analyses were carried out in triplicates and the results expressed in $\mu$ moles of Trolox equivalent/g of sample.

\section{Bacterial culture conditions and plate counts}

Strains of Lactobacillus paracasei L-431, L. acidophilus LA-5, and Bifidobacterium longum BB-46 were provided as fresh cultures by Christian Hansen (Copenhagen, Denmark) and maintained at $-80^{\circ} \mathrm{C}$ in MRS broth with glycerol.

Lactobacillus L-431 and LA-5 strains were individually reactivated in MRS broth (Acumedia, Baltimore, USA). The Bifidobacterium BB-46 strain was activated in MRS broth supplemented with Lcysteine $(0.05 \%)$. The three strains were cultured at $37^{\circ} \mathrm{C}$ for 24 hours. The cells were centrifuged at $2600 \mathrm{rpm} / 10$ minutes at $4{ }^{\circ} \mathrm{C}$ and washed with a saline solution $(0.85 \%)$.

MRS agar (Himedia, India) and acidified MRS agar ( $\mathrm{pH}$ 5.4) with incubation at $37^{\circ} \mathrm{C} / 48$ hours under aerobic and anaerobic conditions were used for counting, respectively, $L$. acidophilus LA-5 and $L$. paracasei L-431. For Bifidobacterium longum BB-46 enumeration, the Bifido Medium BIM-25 agar (Difco, France) was used, with cultivation at $37^{\circ} \mathrm{C} / 72 \mathrm{~h}$ under anaerobic conditions (Anaerogen Anaerobic System, Probac do Brasil), as previously described by Bianchi et al. (2014).

Survival of L. paracasei L-431, L. acidophilus LA-5, and $B$. longum $B B-46$ under in vitro simulated gastrointestinal conditions

The resistance of the probiotic strains in combination with the acerola by-product was determined according to the model described by Buriti et al. (2010) with some modifications. A volume of $10 \mathrm{~mL}$ of each strain suspension along with the by-product were added to $90 \mathrm{~mL}$ of $0.85 \%$ saline solution (w/v), and homogenised in a Bag Mixer (Interscience, St Nom). Aliquots of $10 \mathrm{~mL}\left(10^{8} \mathrm{CFU} . \mathrm{mL}^{-1}\right)$ were transferred to sterile bottles and the $\mathrm{pH}$ of the solution was adjusted to 2.07-2.72 with a $1 \mathrm{M} \mathrm{HCl}$ solution (Merck). Pepsin (Pepsin from porcine gastric mucosa, Sigma-Aldrich) and lipase solution (Amano Lipase G, Sigma-Aldrich) were added at sufficient quantities to achieve concentrations of $3 \mathrm{~g} / \mathrm{L}$ and $0.9 \mathrm{mg} / \mathrm{L}$ in the final solution, respectively. Next, the bottles were incubated in a water bath (CT232, Cientec, Belo Horizonte, BR) at $37^{\circ} \mathrm{C}$ under constant stirring at $150 \mathrm{rpm}$ for two hours (gastric phase). After 2 hours of incubation, $\mathrm{pH}$ was adjusted to 4.21-5.03 using sterile alkaline solution $\left(150 \mathrm{~mL}\right.$ of $1 \mathrm{~N} \mathrm{NaOH}+11.16 \mathrm{~g} / \mathrm{L}$ of $\left.\mathrm{PO}_{4} \mathrm{H}_{2} \mathrm{Na}\right)$. In the next step, a bile (bile from bovine and ovine, Sigma-Aldrich) and pancreatin (Pancreatin from porcine pancreas, Sigma-Aldrich) solution was added at sufficient concentrations so that the final solution contained $10 \mathrm{~g} / \mathrm{L}$ and $1 \mathrm{~g} / \mathrm{L}$, respectively. The samples were again incubated at $37^{\circ} \mathrm{C}$ for two hours (Enteric Phase I). At the end of the enteric Phase I, the $\mathrm{pH}$ was adjusted to 6.12-6.97, and samples were added to the Pancreatin and Bile solution (keeping the concentration at $10 \mathrm{~g} / \mathrm{L}$ and $1 \mathrm{~g} / \mathrm{L}$ of the final solution, respectively), and a new incubation took place at $37^{\circ} \mathrm{C}$ for two hours under constant agitation (enteric phase II), totalling 6 hours of experiment. For each phase of the assessment (0,2, 4, and 6 hours), samples were collected to conduct the selected strains enumeration.

\section{Scanning electron microscopy}

To verify morphological changes of the selected probiotic with the acerola by-product under simulated gastrointestinal conditions (using the gastrointestinal in vitro model described by Buriti et al. (2010)), a scanning electron microscopy was performed. This part of the study was performed according to the methodology proposed by Matias et al. (2016). 
Samples of each phase (gastric and enteric), as well as a sample of the microorganism (in saline solution at $0.85 \% \mathrm{w} / \mathrm{v}$ ) without passing through any simulated gastrointestinal juices were centrifuged $(6500 \mathrm{rpm} /$ $10 \mathrm{~min}$.) and the supernatants were discarded. The pellet was suspended in a $\mathrm{NaCl}(0.9 \% \mathrm{w} / \mathrm{v})$ solution until a final concentration of $5 \log \mathrm{CFU} \mathrm{mL} \mathrm{m}^{-1}$ was reached. Aliquots of $1 \mathrm{~mL}$ of cell suspension were fixed for $2 \mathrm{~h}$ in $2 \%$ glutaraldehyde $(\mathrm{v} / \mathrm{v})$, followed by fixation in osmium tetroxide for $2 \mathrm{~h}$. Next, the membranes were washed 3 times in purified water and dehydrated, with a solution of $70 \%$ ( 15 minutes, twice), 95\% (15 minutes, twice) and 100\% ethanol ( 15 minutes, four times), and then dried to a critical point of $\mathrm{CO}_{2}$. The dried membranes were transferred to an aluminium base by a sputtering machine, coated with gold and analysed using scanning electron microscopy at $2.5 \mathrm{Kv}$. (JEOL JSM-7401F, JEOL, Tokyo, Japan) (Matias et al. 2016).

\section{Action of selected combination on a gut microbiota model (SHIME ${ }^{\circledR}$ )}

The action of the selected combination (acerola by product and probiotic strain) under simulated gut microbiota conditions was determined using the SHIME® system. SHIME® is a dynamic model (from Ghent University and ProDigest) which simulates the human intestinal microbial ecosystem. The SHIME® is composed by five double-jacketed vessels simulating the stomach (vessel 1), the duodenum (vessel 2), and the ascending (colon vessel 3), transverse (colon vessel 4), and descending (colon vessel 5) colons. This dynamic system is connected with a software, which controls the $\mathrm{pH}$, residence time, and temperature of each vessel as described by Molly et al. (1994) and Possemiers et al. (2004).

The passage of the combination through the stomach was simulated by the vessel 1 with $\mathrm{HCl}$ for the regulation of $\mathrm{pH}$, along with a feeding medium [carbohydrate-based medium that allows the adaptation to specific environmental conditions of the ascending, transverse, and descending colons in terms of $\mathrm{pH}$ range, retention time, and available carbon sources (Molly et al. 1994). The feeding medium composition was previously described by Possemiers et al. (2004).

The passage of the combination (acerola by-product with BB-46) through the duodenum was simulated by the vessel 2 with $60 \mathrm{~mL}$ of artificial pancreatic juice $\left(12.5 \mathrm{~g} / \mathrm{L}\right.$ of $\mathrm{NaHCO}_{3}, 6 \mathrm{~g} / \mathrm{L}$ of Oxgall, and $0.9 / \mathrm{L} \mathrm{g}$ of pancreatin) at a rate of $4 \mathrm{~mL} / \mathrm{min}$. for 15 minutes (Molly et al. 1994; Possemiers et al. 2004).
In order to maintain the homogeneity in each vessel, a magnetic stirrer was used. The system was maintained in anaerobic conditions through $\mathrm{N}_{2}$ flushing for $30 \mathrm{~min}$, everyday. The $\mathrm{pH}$ of colon vessels 3,4 , and 5 was automatically adjusted by the addition of $\mathrm{NaOH} 0.5 \mathrm{M}$ or $\mathrm{HCl} 0.1 \mathrm{M}$. For the stomach region, the $\mathrm{pH}$ was automatically adjusted by the addition of $\mathrm{NaOH} \quad 0.5 \mathrm{M}$ and $\mathrm{HCl} 1 \mathrm{M}$ (Molly et al. 1994; Possemiers et al. 2004).

\section{Faecal inoculum}

Before starting the experiments, the colon vessels (V3, $\mathrm{V} 4$, and V5) were inoculated with bacteria from a stool sample of 3 healthy adults (BMI between $18.5-24.9 \mathrm{~kg} / \mathrm{m}^{2}$ and waist circumference $<80 \mathrm{~cm}$ ) which had not consumed probiotic products over the past 3 to 6 months and with no history of antibiotic treatment within a period of six months prior to the study.

As the production of methane gas is directly related to an increase of acetic acid and, consequently, the increase in total short-chain fatty acids, the volunteers classified as methane producers were excluded (Wolever et al. 1991). For this classification, the breath methane dosage of four lean volunteers was performed through a Quintron digital Breathtracker Microlyzer at the Pediatric Gastroenterology Department of the São Paulo Federal University.

$40 \mathrm{~g}$ of faeces ( $\sim 13.5 \mathrm{~g}$ of each donor) belonging to the selected donors (methane values $<3 \mathrm{ppm}$ ), were collected and diluted in phosphate buffer $(200 \mathrm{~mL})$ containing $0.1 \%$ of Na-thioglicolate, $0.05 \mathrm{~mol} / \mathrm{L}$ $\mathrm{NaH}_{2} \mathrm{PO}_{4}$ and $0.05 \mathrm{~mol} / \mathrm{L}$ of $\mathrm{Na}_{2} \mathrm{HPO}_{4}(\mathrm{pH}=6.5)$. The diluted samples were than stirred in a homogeniser (Stirrer model 130, Nortecientífica, Brazil) for 10 minutes and centrifuged for $15 \mathrm{~min}$. at $3000 \mathrm{rpm}$. From the supernatant, $40 \mathrm{~mL}$ were added to vessels 3 , 4 , and 5, which were already filled with a feeding medium at specific volumes, thus allowing the adjustment and stabilisation of the microbial community (Molly et al. 1994).

\section{Study protocol of combinations in a SHIME ${ }^{\circledR}$ reactor}

The study started with 2 weeks of control period, where $200 \mathrm{~mL}$ of the feeding medium entered through the system twice a day. This two weeks are important to stabilise the microbial community and to allow the adaptation of the microbial community to physicochemical and nutritional conditions prevailing in different parts of the colon (Molly et al. 1994; Possemiers et al. 2004). After this period, the 
treatment with the selected combination was started and continued for the next two weeks. The selected combination was added along with the feeding medium $(200 \mathrm{~mL})$, twice a day, with $10^{8} \mathrm{CFU} \mathrm{mL}^{-1}$ of the selected probiotic and $2.5 \%(\mathrm{w} / \mathrm{v})$ of the acerola by-product. After this period, the washout period was initiated, in which $200 \mathrm{~mL}$ of the feeding medium entered the simulator twice a day for two weeks.

\section{Probiotic viability in the stomach and duodenum using the SHIME ${ }^{\circledR}$ model}

The survival of the probiotic microorganism in combination with the acerola by-product, after the passage through the stomach and duodenum regions, was performed weekly. Samples $(5 \mathrm{~mL})$ of the stomach and the duodenum were collected from the SHIME $\AA$, both after 2 hours of entrance into these compartments. Each sample $(1 \mathrm{~mL})$ was suspended in $9 \mathrm{ml}$ of peptone water. Serial dilutions were performed and the inoculation carried out in suitable culture media.

\section{Microbiological analysis}

Samples from the 3 colon vessels throughout the experimental period ( 2 weeks of control, 2 weeks of treatment and of washout) were weekly collected for the plate counts.

The intestinal microbiota composition analysis was based on the enumeration of total anaerobic bacteria, Lactobacillus spp., Bifidobacterium spp., Clostridium spp., and total coliforms, according to Bianchi et al. (2014). Total amount of anaerobic bacteria was determined by plating on Standard Methods agar and anaerobic incubation (Anaerogen Anaerobic System, Probac do Brasil) at $37^{\circ} \mathrm{C} / 48 \mathrm{~h}$. MRS agar with anaerobic incubation (Anaerogen Anaerobic System, Probac do Brasil) at $37^{\circ} \mathrm{C} / 48 \mathrm{~h}$ was used to determine the population of lactobacilli. BIM-25 agar with anaerobic incubation (Anaerogen Anaerobic System, Probac do Brasil) at $37^{\circ} \mathrm{C} / 72 \mathrm{~h}$ was used to determine the population of Bifidobacterium spp. Clostridium spp. was enumerated anaerobically using Reinforced Clostridial Agar at $37^{\circ} \mathrm{C} / 48 \mathrm{~h}$. Petrifilm ${ }^{\mathrm{TM}}$ EC $(3 \mathrm{M})$ with aerobic incubation at $37^{\circ} \mathrm{C} / 48 \mathrm{~h}$ was used to determine the population of total coliforms.

Molecular methods (PCR-DGGE) were used to analyse the behaviour of total bacteria throughout the experimental period. "Isolation of DNA from Stool for Human DNA" (Qiagen, Hilden, Germany) was the protocol used in this study with some modifications according to Bianchi et al. (2014). QIAamp DNA Stool Mini Kit (Qiagen, Germany) was employed to extract DNA from each reactor vessel at each period of study. DNA yield was quantified by using a NanoDrop ND-1000 spectrophotometer (NanoDrop Technologies, USA). The primers used to replicate DNA were 968FGC (5'-CGC CCG GGG CGC GCC CCG GGC GGG GCG GGG GCA CGG GGG GAA CGC GAA GAA CCT TAC-3') and $1401 \mathrm{R}$ (5'-CGG TGT GTA CAA GAC CC-3') (Nübel et al. 1996). DNA polymerisation was performed by using a GoTaq ${ }^{\circledR}$ Green Master Mix (Promega, USA). Samples were amplified in a Veriti ${ }^{\circledR}$ 96-well thermal cycler (Applied Biosystems, USA) by using the following setup: initial denaturation at $94^{\circ} \mathrm{C}$ for $2 \mathrm{~min}, 35$ cycles of denaturation at $94^{\circ} \mathrm{C}$ for $30 \mathrm{~s}$, annealing of primer at $56^{\circ} \mathrm{C}$ for $40 \mathrm{~s}$, elongation at $72^{\circ} \mathrm{C}$ for $1 \mathrm{~min}$ and extension at $72^{\circ} \mathrm{C}$ for $5 \mathrm{~min}$, followed by final cooling to $4{ }^{\circ} \mathrm{C}$.

Electrophoresis was carried out as previously described by Heilig et al. (2002), i.e. in an $8 \%$ polyacrylamide gel with a denaturant gradient of $45-65 \%$ for $16 \mathrm{~h}$ at $85 \mathrm{~V}$ in a $0.5 \times$ TAE buffer at constant temperature of $60^{\circ} \mathrm{C}$. Gels were stained with ethidium bromide, scanned at 400 d.p.i., and further analysed by the BioNumerics 6.0 software (Applied Maths, Kortrijk, Belgium). BioNumerics 6.0 software (Applied Maths, Kortrijk, Belgium) was used to analyse the distance matrices of each DGGE based on the Pearson similarity.

\section{Ammonium $\left(\mathrm{NH}_{4}^{+}\right)$and short-chain fatty acids (SCFAs) analyses}

Samples from the three colon vessels were collected weekly for $\mathrm{NH}_{4}^{+}$and SCFA analyses throughout the experimental period (control, treatment, and washout).

$\mathrm{NH}_{4}^{+}$amounts were determined by a selective ion metre (HI 4101 model, Hanna Instruments) coupled with an ammonia selective-ion electrode (Orion 95-12). The samples $(25 \mathrm{~mL})$ were added to $0.5 \mathrm{~mL}$ of an ammonia $\mathrm{pH}$ ionic strength adjusting solution (Orion). The analyses were performed in triplicates.

For SCFA analysis, the samples $(2 \mathrm{~mL})$ were centrifuged at $14000 \mathrm{rpm}$ for $5 \mathrm{~min}$. Afterwards, $100 \mu \mathrm{L}$ of the supernatant were added in $1900 \mu \mathrm{L}$ of ultrapure water containing $1 \mathrm{~g}$ of $\mathrm{NaCl}, 100 \mu \mathrm{L}$ of crotonic acid, $70 \mu \mathrm{L}$ of isobutanol, and $200 \mu \mathrm{L}$ of $2 \mathrm{M} \mathrm{H}_{2} \mathrm{SO}_{4}$. The SCFAs were analysed using a 2010-Model gas chromatograph (Shimadzu, Japan) equipped with a split/splitless injector, a flame ionisation detector, and a CombiPAL automated sampler for headspace analysis. The SCFAs were separated using a HPINNOWAX column $(30 \mathrm{~m} \times 0.25 \mathrm{~mm} \times 0.25 \mu \mathrm{m})$ (Agilent Technologies, USA). The carrier gas was 
hydrogen and the flow rate was set at $1.45 \mathrm{~mL} / \mathrm{min}$. The temperature of both the injector and the detector was $240^{\circ} \mathrm{C}$ (Adorno et al. 2014).

\section{Statistical analysis}

The significance of the results was investigated with a one-way ANOVA. Individual means were compared by Tukey's test $(p<.05)$ with the BioEstat 5.0 software (IBM, Brazil).

\section{Results}

\section{Chemical composition, total phenolic content and in vitro antioxidant activity of the dried acerola by-product}

The acerola by-product showed high levels of protein $(9.50 \pm 1.10 \mathrm{~g} / 100 \mathrm{~g})$ and carbohydrate $(81.69 \pm 0.10 \mathrm{~g} /$ $100 \mathrm{~g}$ ), among which $56.28 \pm 0.19 \mathrm{~g} / 100 \mathrm{~g}$ corresponded to fibre. Reduced levels of lipid $(1.31 \pm 0.22 \mathrm{~g} / 100 \mathrm{~g})$, ash $(2.33 \pm 0.11 \mathrm{~g} / 100 \mathrm{~g})$, and moisture $(5.17 \pm 0.05 \mathrm{~g} /$ $100 \mathrm{~g}$ ), as well as high values of total phenolic compounds (average of $52.50 \pm 1.25 \mathrm{mg} \mathrm{GAE} / \mathrm{g}$ of dried by-product) were found. The studied dried acerola by-product showed an antioxidant activity of

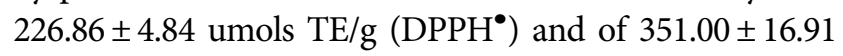
umols TE/g (FRAP).

Survival of L. paracasei L-431, L. acidophilus LA-5, and $B$. longum BB-46 in the presence and absence of acerola by-product under in vitro simulated gastrointestinal conditions and using

\section{SHIME ${ }^{\circledR}$ model}

L. paracasei L-431, L. acidophilus LA-5, and B. longum BB-46, either in combination with the acerola byproduct or not, were exposed to in vitro simulated gastrointestinal conditions, and the results are shown in Figure 1.

The by-product improved $(p<.05)$ the survival of L-431 and of BB-46 during their passage through the gastric juice. However, a high decrease in all strains viability, either with or without the acerola by-product, was observed in the enteric phase $(4 \mathrm{~h}$ and $6 \mathrm{~h}$ of viability test). Among the studied bacterial strains, $L$. acidophilus LA-5 was the one with the worst resistance in all phases.

The acerola by-product provided a higher increase in the BB-46 viability (of 5 log cycles) compared to L-431 (2 log cycles) during the gastric phase in comparison with these probiotic strains without it. For this reason and by considering the best survival adaptation strategies of Bifidobacterium strains, BB-46 in combination with the acerola by-product was selected to be tested in the Simulator of Human Intestinal Microbial Ecosystem (SHIME®).

As in the in vitro simulated gastrointestinal test cited above, it was observed that the acerola by-product provided a high survival rate for BB-46 during the gastrointestinal simulation in the SHIME® model (Figure 2).

\section{Scanning electron microscopy}

As can be seen in the electron microscopy (Figure 3), there was a reduction in the population densities of microorganisms, as well as changes in the structure of BB-46 during the enteric phase I ( $4 \mathrm{~h}$ of gastrointestinal test), and a recovery of the population and the bacterial structures during the enteric phase II ( $6 \mathrm{~h}$ of the gastrointestinal test).

In Figure 3(B), the presence of acerola fibres between the cells in the gastric phase can be observed. After 4 hours of experiment, the appearance of certain substances among the cells was observed, making it difficult to observe the microorganisms. In this phase, it was also observed that a few cells lose their form and appear to clew due to adverse conditions (Figure 3(C)). After 6 hours of experiment, there was a restructuring of cells.

\section{Microbial changes during passage through the SHIME ${ }^{\circledR}$ reactor}

Table 1 shows the microbial population of samples taken from each colon vessels (V3, V4 and V5), which simulated the ascending, transverse and descending colons during the experimental period.

There was no significant alteration in the Lactobacillus spp. and Bifidobacterium spp. populations during the treatment period with the acerola byproduct and BB-46, except for colon vessel 4 . However, during the same period, a reduction $(p<.05)$ of one log cycle of Clostridium spp. and of total anaerobes was observed in colon vessels 3,4 and 5. After the washout period, the bacterial counts returned to their initial condition (control period). There was no significant difference regarding total coliforms during the treatment period $(p>.05)$.

The DGGE analysis was used to monitor qualitative changes in the composition and structure of total bacteria in the three colon vessels. A cluster analysis of the DGGE profiles for colon vessel 3 resulted in two separated groups, showing great similarity (78\%) 

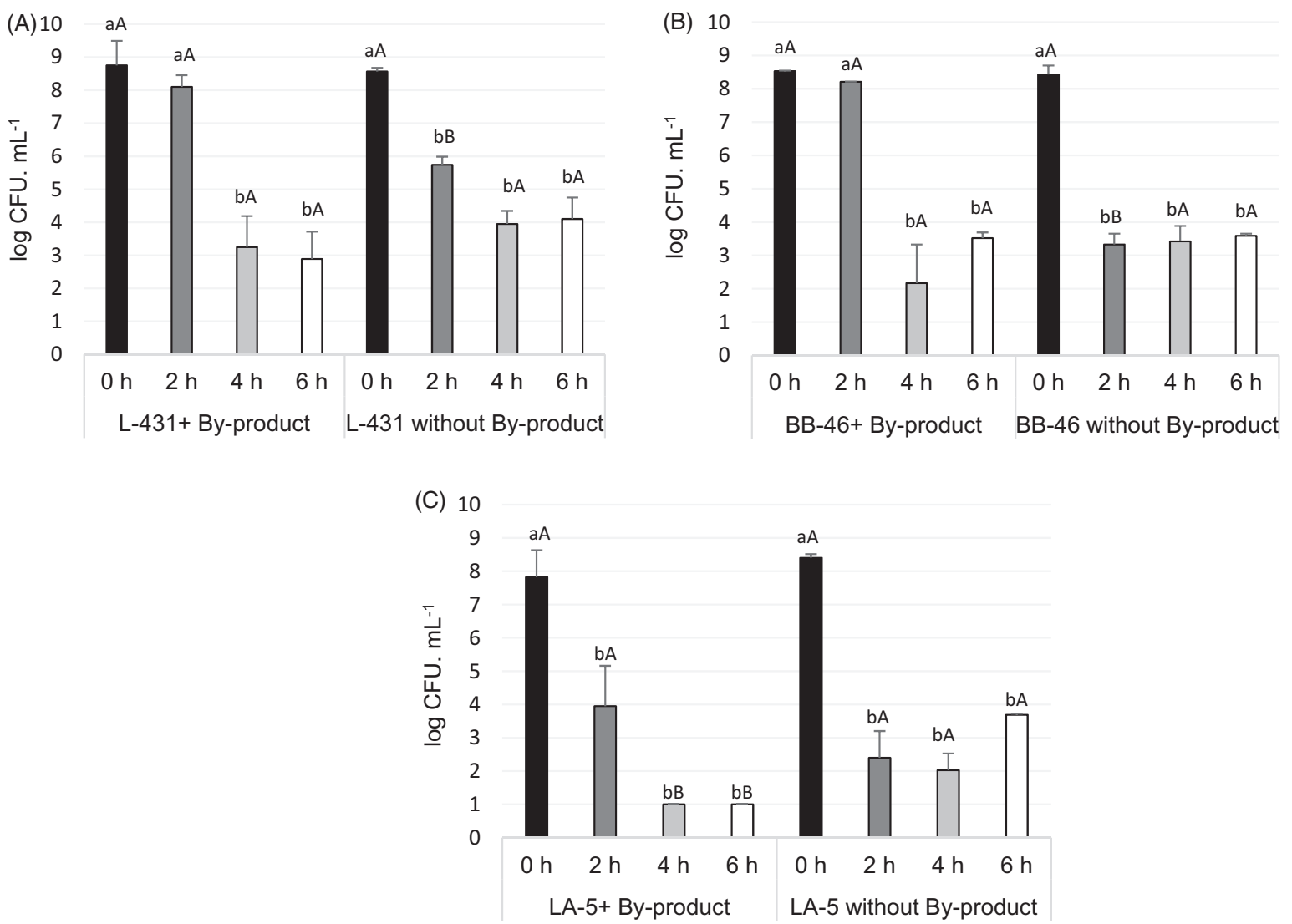

Figure 1. Population (log CFU. $\mathrm{mL}^{-1}$ ) of Lactobacillus paracasei L-431 (A), B. longum BB-46 (B), and L. acidophilus LA-5 (C) either in combination or not with the acerola by-product after the simulated gastrointestinal conditions using the in vitro test. Different uppercase letters represent the difference $(p<.05)$ between different treatments (probiotic with the acerola by-product and without it) whereas different lowercase letters represent the difference $(p<.05)$ between phases $(0,2,4$, and $6 \mathrm{~h})$.

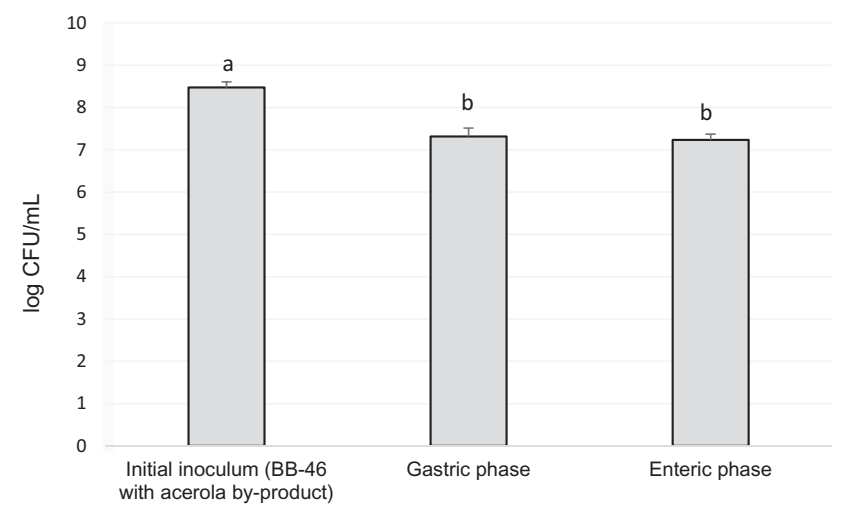

Figure 2. Population ( $\log \mathrm{CFU} / \mathrm{mL}$ ) of $B$. longum BB-46 with acerola by-product after the simulated gastrointestinal conditions using the SHIME ${ }^{\circledR}$ model. Different letters represent a statistically significant difference $(p<.05)$ between the different phases.

between thecontrol and washout period. The treatment period, however, also showed a great similarity (64\%) with the control and the washout period in this region of the colon (Figure 4). In the colon vessel 4, one cluster grouping the treatment period with the washout period was observed, showing that changes in the total bacterial population in the colon 4 vessel was maintained after the treatment period. In the colon vessel 5, a cluster analysis of the DGGE profile showed a single group with the control and the treatment period, which bears great similarity (71\%) with the washout period, thus showing low effects on total bacteria population in the vessel 5 .

\section{Effects on microbial metabolism in SHIME ${ }^{\circledR}: \mathrm{NH}_{4}^{+}$ and SCFA}

Table 2 shows a reduction $(p<.05)$ of $\mathrm{NH}_{4}^{+}$during the treatment period with the acerola by-product in combination with BB-46, but only in colon vessel 3, which simulates the ascending colon. In the other compartments there was no difference $(p<.05)$, except for the washout period in reactors 4 and 5 (Table 2), which showed high values of $\mathrm{NH}_{4}^{+}(p<.05)$.

An increase $(p<.05)$ in short chain fatty acids, particularly butyric acid, was observed during the treatment with the acerola by-product and BB-46 combination in the three colon vessels (Figure 5). 

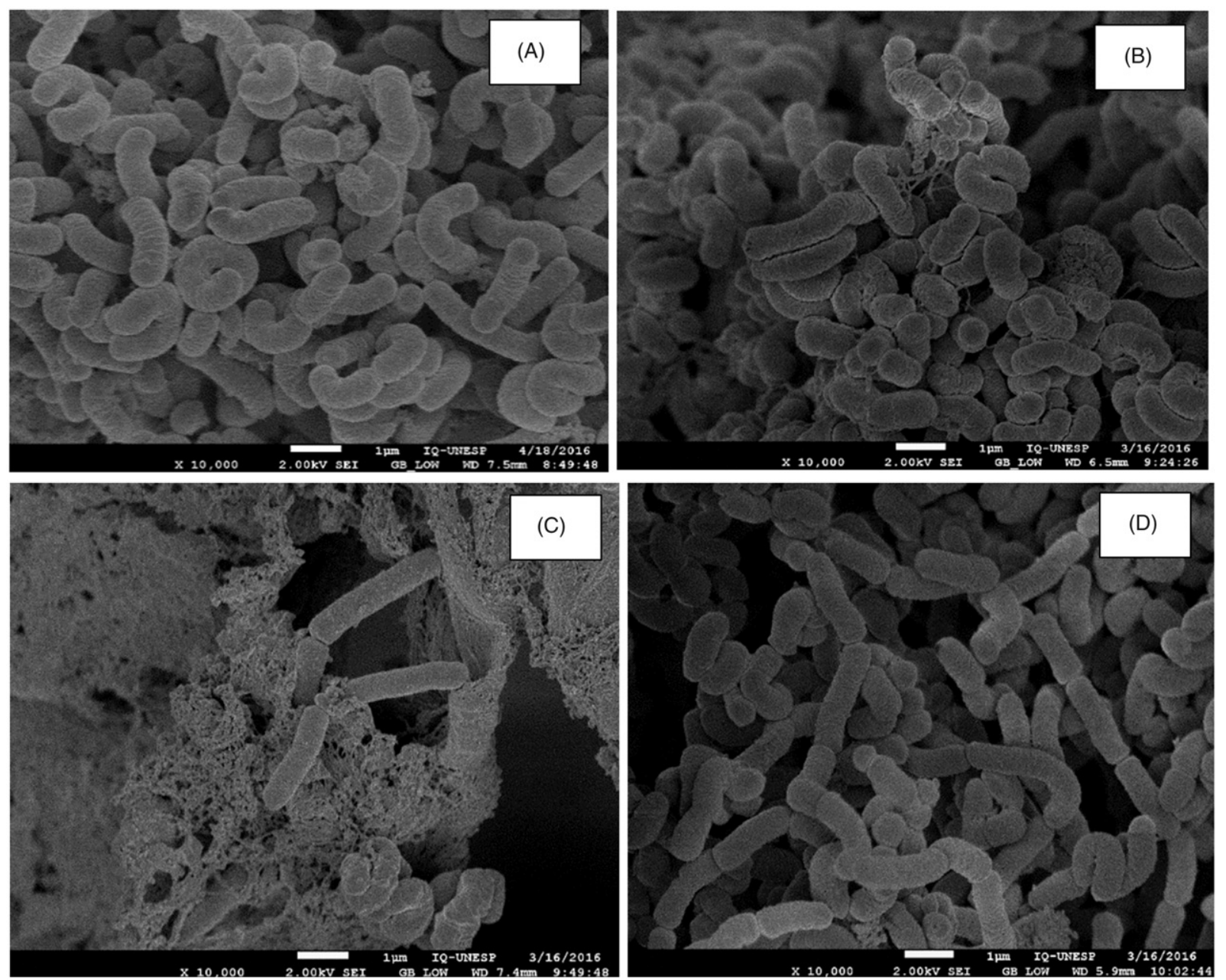

Figure 3. Electron microscopy of Bifidobacterium longum BB-46 under simulated gastrointestinal conditions (A): BB-46 without the acerola by-product, (B): BB-46 + acerola by-product in the gastric phase, (C): BB-46+ acerola by-product in the enteric phase I, (D): BB- $46+$ acerola by-product in the enteric phase II.

Table 1. Microbial counts (log CFU/mL) of different bacterial groups in different vessels that simulate the ascending (colon vessel 3), transverse (colon vessel 4), and descending (colon vessel 5) colons as a result of treatment with the acerola by product + Bifidobacterium longum BB-46.

\begin{tabular}{lccc}
\hline & Control & Treatment & Washout \\
\hline Colon vessel 3 & & & \\
Lactobacillus spp. & $8.59 \pm 0.13^{\mathrm{a}}$ & $8.13 \pm 0.74^{\mathrm{a}}$ & $8.79 \pm 0.01^{\mathrm{a}}$ \\
Bifidobacterium spp. & $8.72 \pm 0.04^{\mathrm{a}}$ & $8.10 \pm 0.61^{\mathrm{a}}$ & $8.88 \pm 0.03^{\mathrm{a}}$ \\
Clostridium spp. & $8.65 \pm 0.08^{\mathrm{a}}$ & $7.60 \pm 0.05^{\mathrm{b}}$ & $8.85 \pm 0.00^{\mathrm{a}}$ \\
Total anaerobes & $8.70 \pm 0.05^{\mathrm{b}}$ & $7.49 \pm 0.07^{\mathrm{c}}$ & $8.87 \pm 0.05^{\mathrm{a}}$ \\
$\quad$ Coliforms & $7.01 \pm 0.43^{\mathrm{a}}$ & $6.64 \pm 1.20^{\mathrm{a}}$ & $7.48 \pm 0.02^{\mathrm{a}}$ \\
Colon vessel 4 & & & \\
Lactobacillus spp. & $8.21 \pm 0.17^{\mathrm{a}}$ & $7.54 \pm 0.37^{\mathrm{b}}$ & $8.12 \pm 0.04^{\mathrm{ab}}$ \\
Bifidobacterium spp. & $8.29 \pm 0.28^{\mathrm{a}}$ & $7.50 \pm 0.28^{\mathrm{b}}$ & $8.16 \pm 0.02^{\mathrm{ab}}$ \\
Clostridium spp. & $8.35 \pm 0.14^{\mathrm{a}}$ & $7.25 \pm 0.01^{\mathrm{b}}$ & $8.20 \pm 0.05^{\mathrm{a}}$ \\
Total anaerobes & $8.44 \pm 0.30^{\mathrm{a}}$ & $7.43 \pm 0.02^{\mathrm{b}}$ & $8.33 \pm 0.01^{\mathrm{a}}$ \\
Coliforms & $7.19 \pm 0.62^{\mathrm{a}}$ & $6.78 \pm 1.48^{\mathrm{a}}$ & $7.07 \pm 0.02^{\mathrm{a}}$ \\
Colon vessel 5 & & & \\
Lactobacillus spp. & $7.74 \pm 0.32^{\mathrm{a}}$ & $7.35 \pm 0.53^{\mathrm{a}}$ & $7.40 \pm 0.03^{\mathrm{a}}$ \\
Bifidobacterium spp. & $8.07 \pm 0.05^{\mathrm{a}}$ & $7.30 \pm 0.53^{\mathrm{a}}$ & $7.38 \pm 0.11^{\mathrm{a}}$ \\
Clostridium spp. & $8.38 \pm 0.13^{\mathrm{a}}$ & $7.12 \pm 0.11^{\mathrm{b}}$ & $8.09 \pm 0.07^{\mathrm{a}}$ \\
Total anaerobes & $8.30 \pm 0.03^{\mathrm{a}}$ & $7.20 \pm 0.09^{\mathrm{b}}$ & $8.19 \pm 0.15^{\mathrm{a}}$ \\
Coliforms & $7.95 \pm 0.16^{\mathrm{a}}$ & $7.85 \pm 1.44^{\mathrm{a}}$ & $7.41 \pm 0.01^{\mathrm{a}}$ \\
\hline
\end{tabular}

Different letters on the same line represent a statistically significant difference $(p<.05)$ between different periods of the experiment for the same microorganism group.
During the treatment period, an increase of 3.19, 2.60 and 4.93 folds in butyric acid and 1.25, 1.06 and 2.54 folds in propionic acid was observed, respectively, in colon vessels 3, 4, and 5. Acetic acid increased 100\% in all the regions of colon.

\section{Discussion}

In this study, we first analysed the chemical composition, total phenolic content and the in vitro antioxidant activity of the dried acerola by-product. Next, we assessed the survival of three different bacterial strains (Lactobacillus acidophilus LA-5, Lactobacillus paracasei L-431 and Bifidobacterium longum BB-46) combined with acerola by-product under in vitro gastrointestinal conditions and, finally we investigated the effects of the combination with the best probiotic survival results on human gut microbiota using SHIME® model. 

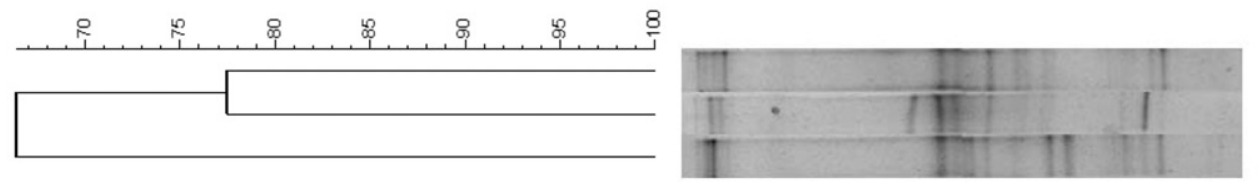

V3C

V3W

V3T

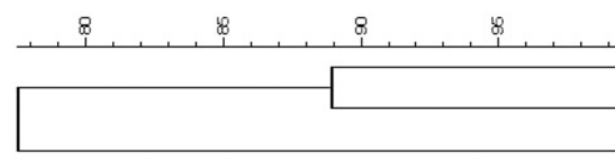

8

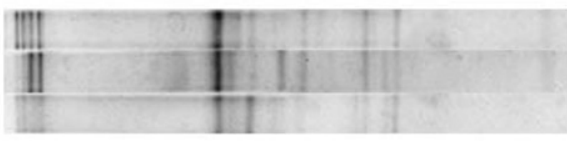

V4T

$\mathrm{V} 4 \mathrm{~W}$

V4C
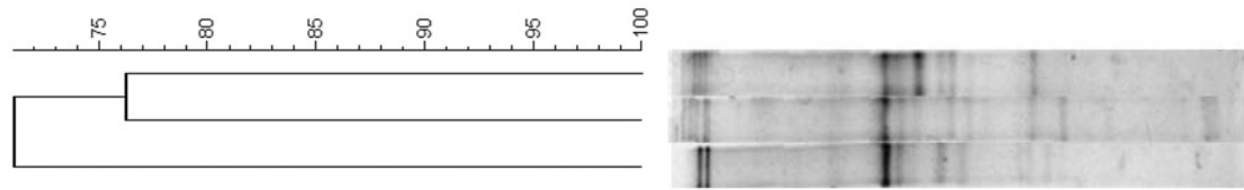

V5C

V5T

V5W

Figure 4. Cluster analysis of the DGGE profiles of total bacteria in different vessels that simulate the ascending (colon vessel 3), transverse (colon vessel 4), and descending (colon vessel 5) colons as a result of treatment with the acerola by product + Bifidobacterium longum BB-46. T: treatment period, C: Control period. W: Washout period.

The dried acerola by-product showed an excellent chemical composition, which were consistent with previous reports of Marques et al. (2013). On the other hand, Abud and Narain (2009) as well as Sousa et al. (2011) found different composition results. According to Marques et al. (2013), fibre, fat, ash and protein contents of acerola by-product can vary from 15.33 to $70.60 \mathrm{~g} / 100 \mathrm{~g}, 0.57$ to $5.62 \mathrm{~g} / 100 \mathrm{~g}, 0.65$ to $6.08 \mathrm{~g} / 100 \mathrm{~g}$, and 0.56 to $9.572 \mathrm{~g} / 100 \mathrm{~g}$, respectively. Acerola composition may vary due to different geographical locations, cultivation practices, rainfall patterns, exposure to sunshine, genetic traits and especially its maturation stage (Silva et al. 2016).

The high content of phenolic compounds and antioxidant activity of acerola by-product have also been reported by several studies (using Folin-Ciocalteu reagent, $\mathrm{DPPH}^{\bullet}$ scavenging and FRAP) (Oliveira et al. 2009; Rufino et al. 2010; Sousa et al. 2011; Silva et al. 2014), showing that the acerola by-product presents higher phenolic compounds and antioxidant activity when compared to other by-products of fruits like guava, pineapple, papaya and cupuaçu among others (Oliveira et al. 2009; Rufino et al. 2010; Sousa et al. 2011; Silva et al. 2014).

Several food ingredients as proteins, fibres and other carbohydrates can enhance the probiotic survival (Ranadheera et al. 2012; Sendra et al. 2016). The acerola by-product chemical composition showed high contents of protein, carbohydrates and fibres, which could have contributed to the improvement of the Lactobacillus L-431 and Bifibibacterium longum BB-46 survival during the gastrointestinal conditions $(2 \mathrm{~h}$ of viability test).
Table 2. $\mathrm{NH}_{4}^{+}$production $(\mathrm{mmol} / \mathrm{L})$ in different vessels that simulate the ascending (colon vessel 3 ), transverse (colon vessel 4), and descending (colon vessel 5) colons as a result of treatment with the acerola by product + Bifidobacterium longum BB-46.

\begin{tabular}{lccc}
\hline & Ascending colon & Transverse colon & Descending colon \\
\hline Control period & $25.16 \pm 0.88^{\mathrm{A}}$ & $27.39 \pm 1.69^{\mathrm{A}}$ & $24.77 \pm 0.75^{\mathrm{A}}$ \\
Treatment period & $16.40 \pm 4.80^{\mathrm{B}}$ & $25.82 \pm 2.00^{\mathrm{A}}$ & $25.77 \pm 1.49^{\mathrm{A}}$ \\
Washout period & $23.70 \pm 9.40^{\mathrm{AB}}$ & $38.17 \pm 5.82^{\mathrm{B}}$ & $40.33 \pm 2.07^{\mathrm{B}}$ \\
\hline
\end{tabular}

Different letters in the same column represent a significant difference $(p<.05)$ between different periods of the experiment for the same vessel.

In addition, the great content of phenolic compounds found in the acerola by-product can also have contributed to the probiotics survival during the gastrointestinal conditions. According to Valero-Cases et al. (2017), some phenolic compounds can provide high viability to lactic acid bacteria after in vitro digestions, especially for Bifidobacterium strains, which present higher metabolism of phenolic compounds (Valero-Cases et al. 2017).

The low bacterial survival rate during the enteric phase ( $4 \mathrm{~h}$ and $6 \mathrm{~h}$ of viability test), of all studied strains, can be attributed to the presence of bile salts. According to Saarela et al. (2000), bile salts are toxic to cells because they disrupt the cellular membrane structure and, therefore, bile salt tolerance is considered one of the required characteristics for the survival of lactic acid bacteria in the duodenum. Although intrinsic bile tolerance appears to be strain dependent, both lactobacilli and bifidobacteria can progressively adapt to the presence of bile salts (Ruiz et al. 2013). Despite the low survival rate of BB-46 

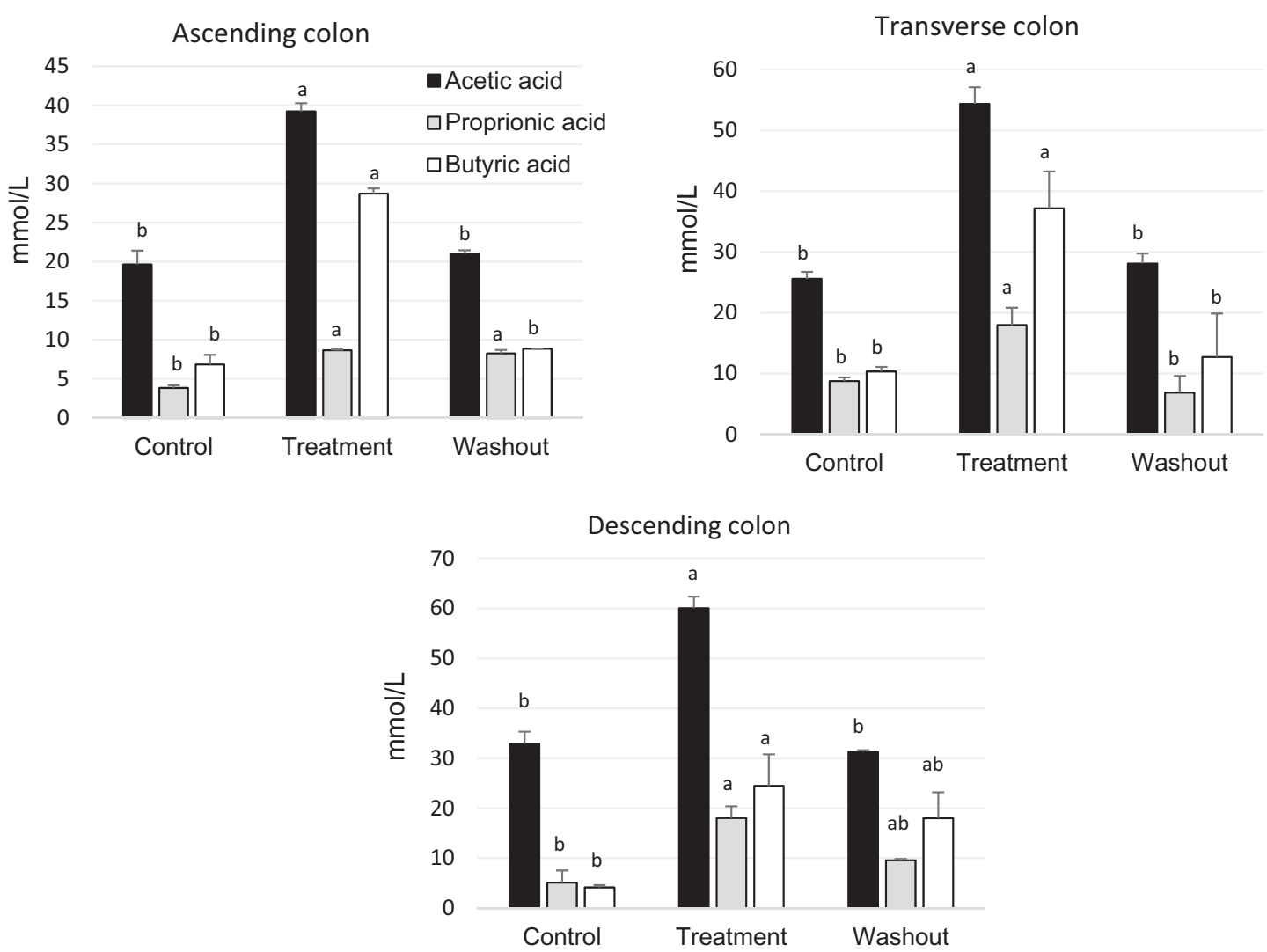

Figure 5. Metabolic activity of short-chain fatty acid (SCFA): acetic, propionic, and butyric acids in different vessels that simulate the ascending (colon vessel 3), transverse (colon vessel 4), and descending (colon vessel 5) colons as a result of treatment with the acerola by product + Bifidobacterium longum BB-46. Different letters represent a significant difference $(p<.05)$ between different phases (control, treatment, and washout) for the same SCFA.

found in the plate counts during the end of the enteric phase (after $6 \mathrm{~h}$ ), the electron microscopy revealed morphological restructuring and high microbial density after this period.

L. acidophilus LA-5 showed the worst survival rate in all the phases. According to Klu and Chen (2015) the survival of probiotic cells under simulated gastric and enteric conditions depends on the probiotic species/strain variability. Still according to these authors, Bifidobacterium strains usually have higher survival rates than Lactobacillus strains. Bedani et al. (2013) reported that LA-5 was more sensitive than Bb-12 to the simulated gastrointestinal conditions. In this mentioned study, Bifidobacterium animalis Bb-12 maintained a mean population of about $8 \log \mathrm{CFU} / \mathrm{g}$, while L. acidophilus La-5 could only maintain a mean population of less than $5 \log \mathrm{CFU} / \mathrm{g}$ during the gastrointestinal test.

As the Bifidobacterium BB-46 showed, in this study, the best survival results during the in vitro gastrointestinal test, this bacteria was selected to be tested in SHIME® model along with the acerola byproduct. During the treatment with the Bifidibacterium BB-46 and acerola by-product in
SHIME® model, a reduction in Clostridium spp. and total anaerobics was observed. According to Macfarlane and Cummings (1991), some strains of Bifidobacterium produce mainly lactic and acetic acids that decrease the $\mathrm{pH}$ of the colon, inhibiting the growth of many pathogenic bacteria such as some species of Clostridium. Although some species of the genus Clostridium are associated with the production of short-chain fatty acids, which are beneficial to health (Possemiers et al. 2010), some species may be harmful due to their metabolic activity and pathogenic character (Montesi et al. 2005). The reduction of Clostridium spp. and total anaerobes may also have been a reflex of a hypothetical increase of specific bacterial groups (stimulated by the acerola by-product components), generating a competitive environment.

Although the DGGE results suggest no effects of the combination on total bacteria in SHIME® model, significant changes in the gut microbiota metabolism (SCFA and $\mathrm{NH}_{4}^{+}$) were noticed.

A decrease in $\mathrm{NH}_{4}^{+}$was observed in the ascending colon during the treatment with the acerola by-product and BB-46. According to Smith and MacFarlane (1998), the levels of $\mathrm{NH}_{4}^{+}$are directly affected by the 
presence of specific carbohydrates. This fact occurs due to the preference of the intestinal microorganisms to carbohydrates, inhibing the amino acids fermentation in favour of carbohydrate (Ito et al. 1993). Thus, in the present study, the high fibre or/and other carbohydrate content present in acerola by-product may have contributed to these results. Moreover, as already mentioned, the Bifidobacterium spp. produce lactic and acetic acids that decrease the colon $\mathrm{pH}$, inhibiting the growth of some pathogenic bacteria such as some species of Clostridium, which use amino acids as source of nitrogen, carbon, and energy, generating $\mathrm{NH}_{4}^{+}$as a metabolite (Macfarlane and Cummings 1991).

The reduction of $\mathrm{NH}_{4}^{+}$, regardless of which colon portion it takes place, is considered beneficial since $\mathrm{NH}_{4}^{+}$corresponds to one of the products of protein degradation which is generated by the gut bacteria, and is considered a metabolite that negatively affects the intestinal health (Davila et al. 2013).

A significant increase $(p<.05)$ in SCFA was also observed during the treatment with the combination BB-46 and acerola by-product in the three regions of colon. According to Bedani and Rossi (2009), the production of SCFA depends on the available substrates and the microorganisms present in the gastrointestinal tract. As previously shown, the acerola by-product has high polyphenol and fibre content. In this context, according to Tuohy et al. (2012), the production of SCFA may occur due to the use of fibre or polyphenols present in food, either in combination or not. According to these authors, in vitro studies have shown that both can be metabolised by the gut microbiota, resulting in a SCFA increase. The hydrolysis of polyphenols by colonic microbiota can increase the bioavailability, and possibly the biological activity of polyphenols that reach the colon region. According to Tuohy et al. (2012), the intestinal microbiota has an extensive hydrolytic activity and the ability to break down many complex polyphenols into smaller phenolic acids, which can be absorbed across the intestinal mucosa, thus increasing the production of SCFA. The same occurs with fibres. According to Shen et al. (2012), a population with a higher intake of dietary fibre tends to have higher concentrations of SCFA in faeces.

Although a large number of amino acid fermenters are present in the colon region, the majority of the gut microorganisms have predominantly saccharolytic metabolism and as a consequence, carbohydrate availability becomes an important nutritional factor, controlling the composition and metabolic activity of the intestinal microbiota (Davila et al. 2013). Thus, the presence of fibres and other carbohydrates present in acerola by-product may have been a stimulating factor of bacteria with saccharolytic metabolism generating SCFA.

The presence of Bifidobacterium longum BB-46 may also have had a contribution to the increased production of SCFA. Several studies have shown that lactate and/or acetate produced by bifidobacteria is used by some bacterial genus as Roseburia, Eubacterium and Anaeroestipes, which convert these metabolites into SCFA (Belenguer et al. 2006; Flint et al. 2015).

In this study, among the SCFAs, the butyric acid was the one with highest increase. According to Chakraborti (2015), butyric acid has been found to increase mitochondrial activity, prevent metabolic endotoxemia, improve insulin sensitivity, exhibit colon cancer-preventive effects, increase intestinal barrier function and protect against diet-induced obesity without causing hypophagia.

\section{Conclusions}

The current study showed that Bifidobacterium longum BB-46 exhibited better gastrointestinal resistance then Lactobacillus acidophilus LA-5 and Lactobacillus paracasei L-431 when combined with the acerola byproduct. Bifidobacterium longum BB-46 with acerola by-product reduced ammonium ions (in ascending colon) and provided an increase in acetic, butyric, and propionic acids concentrations in all colon vessels. Moreover, this study was able to show the excellent chemical composition and the high antioxidant activity of the acerola by-product. The results suggest that BB-46 with acerola by-product has a positive effect on the gut microbiota metabolism and might be used in new studies about functional products development, additionally generating an added value to the acerola by-product, often discarded by industries. However, new studies using more robust methods to analyse changes in intestinal microbiota, such as $16 \mathrm{~S}$ sequencing, are necessary to understand the action of Bifidobacterium longum BB-46 and acerola by-product, combined or not, on the intestinal microbiota composition, and consequently, better understand the microbial metabolism.

\section{Acknowledgements}

The study is part of the "Bioactive components from byproducts of food processing used in a synbiotic approach for improving human health and well-being (BioSyn)" project, within the frame of the international thematic project 
"Strategic Research Collaboration in Food Science in the State of São Paulo, Brazil and Denmark - 2013" FAPESP/ DCSR. The authors also wish to thank Chr. Hansen for providing the microorganisms for the study and São Paulo Federal University (UNIFESP) for the permission to use the equipment "Quintron digital Breathtracker Microlyzer".

\section{Disclosure statement}

The authors report no conflicts of interest. The authors alone are responsible for the content and writing of this article.

\section{Funding}

This work was supported by Fundação de Amparo à Pesquisa do Estado de São Paulo (FAPESP) [Projects number 2013/50506-8, 2015/13965-0 and 2015/08228-6]; Coordenação de Aperfeiçoamento de Pessoal de Nível Superior (CAPES); and Conselho Nacional de Desenvolvimento Científico e Tecnológico (CNPq).

\section{References}

Abud AKS, Narain N. 2009. Incorporação da farinha de resíduo do processamento de polpa de fruta em biscoitos: uma alternativa de combate ao desperdício. Brazilian J Food Technol. 12:257-265.

Adorno MAT, Hirasawa JS, Varesche MBA. 2014. Development and validation of two methods to quantify volatile acids (C2-C6) by GC/FID: headspace (automatic and manual) and liquid-liquid extraction (LLE). Am J Anal Chem. 05:406-414.

Anvisa. 2012. Agência Nacional de Vigilância Sanitária (Anvisa) [National Health Surveillance Agency]. RDC no 54, de 12 de novembro de 2012. Diário da União

AOAC. 2010. Official methods of analysis of the Association official analytical chemist, 18 th. Association official analytical chemist. Arlington: AOAC.

Bedani R, Rossi EA. 2009. Microbiota intestinal e probióticos: implicações sobre o câncer do cólon. J. Port Gastrenterol. 16:19-28.

Bedani R, Rossi EA, Saad SMI. 2013. Impact of inulin and okara on Lactobacillus acidophilus La-5 and Bifidobacterium animalis Bb-12 viability in a fermented soy product and probiotic survival under in vitro simulated gastrointestinal conditions. Food Microbiol. 34:382-389.

Belenguer A, Duncan SH, Calder AG, Holtrop G, Louis P, Lobley GE, Flint HJ. 2006. Two Routes of Metabolic Cross-Feeding between Bifidobacterium adolescentis and butyrate-producing anaerobes from the human gut. Appl Environ Microbiol. 72:3593-3599.

Benzie IFF, Strain JJ. 1996. The Ferric Reducing Ability of Plasma (FRAP) as a Measure of "antioxidant power" :the FRAP assay”. Anal Biochem. 239:70-76.

Bianchi F, Rossi EA, Sakamoto IK, Adorno MAT, Van de Wiele T, Sivieri K. 2014. Beneficial effects of fermented vegetal beverages on human gastrointestinal microbial ecosystem in a simulator. Food Res Int. 64:43-52.

Brand-Williams W, Cuvelier ME, Berset C. 1995. Use of a free radical method to evaluate antioxidant activity. LWT - Food Sci Technol. 28:25-30.

Buriti FCA, Castro IA, Saad SMI. 2010. Viability of Lactobacillus acidophilus in synbiotic guava mousses and its survival under in vitro simulated gastrointestinal conditions. Int J Food Microbiol. 137:121-129.

Chakraborti CK. 2015. New-found link between microbiota and obesity. World J Gastrointest Pathophysiol. 6:110.

Davila AM, Blachier F, Gotteland M, Andriamihaja M, Benetti PH, Sanz Y, Tomé D. 2013. Intestinal luminal nitrogen metabolism: Role of the gut microbiota and consequences for the host. Pharmacol Res. 68:95-107.

Duarte-Almeida JM, Santos RJ, Genovese MI, Lajolo F. 2006. Avaliação da atividade antioxidante utilizando sistema B-Caroteno/Ácido Linoléico e método de seqüestro de radicais $\mathrm{DPPH}^{\bullet}$. Ciênc Tecnol Aliment. 26:446-452.

Duda-Chodak A. 2012. The inhibitory effect of polyphenols on human gut microbiota. J Physiol Pharmacol. 63:497-503.

Flint HJ, Duncan SH, Scott KP, Louis P. 2015. Links between diet, gut microbiota composition and gut metabolism. Proc Nutr Soc. 74:13-22.

Genovese MI, Santos RJ, Hassimotto NMA, Lajolo F. 2003. Determinação do conteúdo de fenólicos totais em frutas. Rev Bras Ciências Farm. 39:67-69.

Gorinstein S, Poovarodom S, Leontowicz H, Leontowicz M, Namiesnik J, Vearasilp S, Haruenkit R, Ruamsuke P, Katrich E, Tashma Z. 2011. Antioxidant properties and bioactive constituents of some rare exotic Thai fruits and comparison with conventional fruits. In vitro and in vivo studies. Food Res Int. 44:2222-2232.

Heilig HGHJ, Zoetendal EG, Vaughan EE, Marteau P, Akkermans ADL, De Vos WM. 2002. Molecular diversity of Lactobacillus spp. and other lactic acid bacteria in the human intestine as determined by specific amplification of $16 \mathrm{~S}$ Ribosomal DNA molecular diversity of Lactobacillus spp. and other lactic acid bacteria in the human intestine. Appl Environ Microbiol. 68:114-123.

Hoover DG. 2014. Bifidobacterium. Encycl Food Microbiol. $1: 216-222$.

IBRAF. 2009. IBRAF Instituto Brasileiro de Frutas. Brazilian fruits in demand. [Accessed 2016 September]. http://www. ibraf.org.br/imprensa/0901_FrutasBrasileirasAscensao.asp.

Ito M, Kimura M, Deguchi Y, Miyamori-Watabe A, Yajima T, Kan T. 1993. Effects of transgalactosylated disaccharides on the human intestinal microflora and their metabolism. J Nutr Sci Vitaminol. 39:279-288.

Junior JE, Neiva JNM, Rodriguez NM, Pimentel JCM, Lôbo RNB. 2005. Intake and dry matter digestibility of byproducts of fruit processer in sheep. Rev Bras Zootec. 34:659-669.

Kavanaugh DW, O’Callaghan J, Buttó LF, Slattery H, Lane J, Clyne M, Kane M, Joshi L, Hickey RM. 2013. Exposure of Bifidobacterium longum subsp. infantis to milk oligosaccharides increases adhesion to epithelial cells and induces a substantial transcriptional response. PLoS One. 8:e67224.

Klu YAK, Chen J. 2015. Effect of peanut butter matrices on the fate of probiotics during simulated gastrointestinal passage. LWT - Food Sci Technol. 62:983-988. 
Macfarlane GT, Cummings JP. 1991. The colonic flora, fermentation and large bowel digestive function. In: Phillips SF, Pemberton JH, Shorter GR, editors. The large intestine: physiology, pathophysiology and disease. New York: Raven Press; p. 923.

Marques TR, Corrêa AD, Lino JB. d R, Abreu CMP, Simão AA. 2013. Chemical constituents and technological functional properties of acerola (Malpighia emarginata DC.) waste flour. Food Sci Technol. 33:526-531.

Matias NS, Padilha M, Bedani R, Saad SMI. 2016. In vitro gastrointestinal resistance of Lactobacillus acidophilus La5 and Bifidobacterium animalis Bb-12 in soy and/or milk-based synbiotic apple ice creams. Int J Food Microbiol. 234:83-93.

Mezadri T, Villaño D, Fernández-Pachón MS, GarciaParrilla MC, Troncoso AM. 2008. Antioxidant compounds and antioxidant activity in acerola (Malpighia emarginata DC.) fruits and derivatives. J Food Compos Anal. 21:282-290.

Molly K, Woestyne MV, Smet ID, Verstraete W. 1994. Validation of the simulator of the human intestinal microbial ecosystem (SHIME) reactor using microorganism-associated activities. Microb. Ecol Health Dis. 7:191-200.

Montesi A, García-Albiach R, Pozuelo MJ, Pintado C, Goni I, Rotger R. 2005. Molecular and microbiological analysis of caecal microbiota in rats fed with diets supplemented either with prebiotics or probiotics. Int J Food Microbiol. 98:281-289.

Nóbrega EM, Oliveira EL, Genovese MI, Correia RTP. 2015. The impact of hot air drying on the physical-chemical characteristics, bioactive compounds and antioxidant activity of acerola (Malphigia emarginata) residue. J Food Process Preserv. 39:131-141.

Nübel U, Engelen B, Felske A, Snaidr J, Wieshuber A, Amann RI, Ludwig W, Backhaus H. 1996. Sequence heterogeneities of genes encoding $16 \mathrm{~S}$ rRNAs in Paenibacillus polymyxa detected by temperature gradient gel electrophoresis. Sequence heterogeneities of genes encoding 16S rRNAs in Paenibacillus polymyxa detected by temperature gradient gel elect. J Bacteriol. 178:5636-5643.

Oliveira AC, Valentim IB, Silva CA, Bechara EJH, Barros MP, Mano CM, Goulart MOF. 2009. Total phenolic content and free radical scavenging activities of methanolic extract powders of tropical fruit residues. Food Chem. 115:469-475.

Payne AN, Zihler A, Chassard C, Lacroix C. 2012. Advances and perspectives in in vitro human gut fermentation modeling. Trends Biotechnol. 30:17-25.

Possemiers S, Marzorati M, Verstraete W, Van de Wiele T. 2010. Bacteria and chocolate: a successful combination for probiotic delivery. Int J Food Microbiol. 141:97-103.

Possemiers S, Verthé K, Uyttendaele S, Verstraete W. 2004. PCR-DGGE-based quantification of stability of the microbial community in a simulator of the human intestinal microbial ecosystem. FEMS Microbiol Ecol. 49:495-507.

Ranadheera CS, Evans CA, Adams MC, Baines SK. 2012. Probiotic viability and physico-chemical and sensory properties of plain and stirred fruit yogurts made from goat's milk. Food Chem. 135:1411-1418.
Realini CE, Guàrdia MD, Díaz I, García-Regueiro JA, Arnau J. 2015. Effects of acerola fruit extract on sensory and shelf-life of salted beef patties from grinds differing in fatty acid composition. Meat Sci. 99:18-24.

Rufino Md SM, Alves RE, de Brito ES, Pérez-Jiménez J, Saura-Calixto F, Mancini-Filho J. 2010. Bioactive compounds and antioxidant capacities of 18 non-traditional tropical fruits from Brazil. Food Chem. 121:996-1002.

Ruiz L, Margolles A, Sánchez B. 2013. Bile resistance mechanisms in Lactobacillus and Bifidobacterium. Front Microbiol. 4:1-8.

Saarela M, Mogensen G, Fondén R, Matto J, MattilaSandholm T. 2000. Probiotic bacteria: Safety, functional and technological properties. J Biotechnol. 84:197-215.

Sendra E, Sayas-Barberá ME, Fernández-López J, PérezAlvare J. 2016. Effect of food composition on probiotic bacteria viability. In: Watson R., Preedy V., editors. Probiotics, prebiotics, and synbiotics bioactive foods in health promotion. Arizona: University of Arizona; p. 257-269.

Shen Q, Zhao L, Tuohy KM. 2012. High-level dietary fibre up-regulates colonic fermentation and relative abundance of saccharolytic bacteria within the human faecal microbiota in vitro. Eur J Nutr. 51:693-705.

Silva LMR, De Figueiredo EAT, Ricardo NMPS, Vieira IGP, Figueiredo RW, Brasil IM, Gomes CL. 2014. Quantification of bioactive compounds in pulps and byproducts of tropical fruits from Brazil. Food Chem. 143:398-404.

Silva PB, Duarte CR, Barrozo MAS. 2016. Dehydration of acerola (Malpighia emarginata D.C.) residue in a new designed rotary dryer: effect of process variables on main bioactive compounds. Food Bioprod Process. 98:62-70.

Singleton VL, Orthofer R, Lamuela-Raventós RM. 1999. Analysis of total phenols and other oxidation substrates and antioxidants by means of Folin-Ciocalteu reagente. Methods Enzymol. 229:152-178.

Smith EA, MacFarlane GT. 1998. Enumeration of amino acid fermenting bacteria in the human large intestine: Effects of $\mathrm{pH}$ and starch on peptide metabolism and dissimilation of amino acids. FEMS Microbiol Ecol. 25:355-368.

Sousa MSB, Vieira LM, Silva MJM, Lima AD. 2011. Caracterização nutricional e compostos antioxidantes em resíduos de polpas de frutas tropicais. Cienc Agrotec. 35:554-559.

Tuohy KM, Conterno L, Gasperotti M, Viola R. 2012. Upregulating the human intestinal microbiome using whole plant foods, polyphenols, and/or fiber. J Agric Food Chem. 60:8776-8782.

Valero-Cases E, Nuncio-Jáuregui N, Frutos MJ. 2017. Influence of fermentation with different lactic acid bacteria and in vitro digestion on the biotransformation of phenolic compounds in fermented pomegranate juices. J Agric Food Chem. 65:6488-6496.

Wolever TM, Spadafora P, Eshuis H. 1991. Interaction between colonic acetate and propionate in humans. Am J Clin Nutr. 53:681-687.

Woodmansey EJ. 2007. Intestinal bacteria and ageing. J Appl Microbiol. 102:1178-1186. 